typhoid. Early in the war, the bad news came of many cases of tetanus; the heavily manured soil of France was full of tetanus; the very earth that our men were helping to defend was their enemy. It is a great blessing that a wounded man may indeed be safeguarded, with a dose of anti-tetanic serum, against this disease; and a great blessing that our men now are on soil which is fairly free from it.

But typhoid, after all, is the supreme test of the efficiency of an army medical service. We have learned of late years that the infection may be conveyed by flies, and by clouds of dust; we have learned also the danger of infection from mild, unsuspected cases, and from typhoidcarriers; we have left off thinking that typhoid cannot be spread without the help of a "polluted water supply." The present control of typhoid for our Army in France has been won by the bacteriologists; all honour to them :-

Mobile bacteriological laboratories have been installed expressly for this purpose (the early detection of cases). Each laboratory consists of a motor-lorry fitted with a complete bacteriological equipment, and is in charge of a specially-trained officer, and an attendant of the Royal Army Medical Corps.

Moreover, it is the bacteriologists who discovered the protective treatment against the disease. On March 5 we learned what our Army owes to that treatment. Of fifty deaths from typhoid fever among our men on active service, forty-eight had occurred among the non-protected, one in a man protected, and one in a man partly protected. Nobody in his proper senses can doubt that Nature finds it easier to kill the nonprotected than to kill the protected.

It must not be forgotten that by far the most potent weapon in our armoury against typhoid fever has been forged by pathologists, before the war. Inoculation is the surest defence : and to its extensive use must chiefly be attributed the low incidence of this terrible disease in the British Army.

But the whole article ought to be read carefully, not in fragments.

Doubtless, when the hot weather comes, the work of safeguarding the Army's health will be no less arduous than it is now. For the present, let us be thankful for the splendid services rendered by men of science to our defenders, through all the bitter hardship and perils of the past nine months.

Stephen Paget.

\section{THE USE OF ASPHYXIANTS IN} WARFARE.

THE use of asphyxiating gases by the Germans 1 in forcing back the French lines to the north of Ypres has given rise to much conjecture as to the nature of the gases employed, and in a long article in a Sunday paper it is surmised that the gas used was carbon monoxide. The only foundation that can exist for such an opinion is that carbon monoxide is one of the most virulent gaseous poisons known: and that less than I per cent. in air rapidly proves fatal, but inasmuch as all the explosives in general use produce it in large quantities, the smokeless powders in use by
England, France, and Germany, giving approximately $5^{\circ}$ per cent. of the permanent gases formed as carbon monoxide, it is hard to believe that the enormous volume produced by firing the charge in the gun should have no deleterious effect on those using it, whilst the much smaller quantity given on the bursting of the shell should asphyxiate the enemy. The fact is, that carbon monoxide is slightly lighter than air, and when driven out by the explosion in a heated condition diffuses upwards so rapidly that scarcely a trace can be found at the breathing level, but when evolved underground in a confined space many accidents have been caused by its poisonous properties.

Moreover, carbon monoxide is in no sense of the word an asphyxiant, 'frid one of its greatest dangers lies in the fact that air containing a poisonous amount can be readily breathed.

Later reports received on Monday and Tuesday make it evident that it was a true asphyxiant, such as sulphur dioxide, chlorine, or a mixture of the two that was employed, and that the fumes generated in front of the German trenches were borne down by a northerly wind upon the Allies. Some descriptions speak of the burning of some substance which gave a yellowish smoke and gases; others that the gases were contained in steel cylinders, the gases being conducted by hosepipes some little distance in front of the trenches, whilst the men manipulating the cylinders wore divers' helmets, and the first German troops to charge over the gassed area wore smoke helmets or respirators. It is further probable that some shells containing a liquid giving gases of an asphyxiating character were also employed.

It seems to be clear from various descriptions that the gases floated close to the ground for a considerable distance, producing an effect of asphyxiation, which was felt as far as the Allies' second lines.

Both sulphur dioxide and chlorine would have produced the effects described, and the cylinders spoken of might have contained these gases in a iiquefied form, whilst it is probable that shells used for asphyxiating purposes would be charged with chloride of sulphur which would itself decompose in moist air or in contact with water into sulphur dioxide, hydrochloric acid, and sulphur, or, if fired by the bursting of the shell, would give sulphur dioxide and chlorine.

Both sulphur dioxide and chlorine satisfy the requirements of being more than double the weight of air, and so might remain near the ground, diffusion being only slow, but it is difficult to understand how sufficient quantities of either gas were produced to render the air irrespirable at the distance of the Allies' lines from the German trenches.

\section{RICHARD LYDEKKER, F.R.S.}

ROTH zoologists and geologists lament the $B$ death on April 16 of Mr. Richard Lydekker, who had been for more than thirty years one of the most active workers in the natural history sciences. Born in 1849 , of Dutch descent, he was educated at Cambridge, where he graduated

No. 2374, VOL. 95] 
in 1871 , and was placed second in the first class of the Natural Science Tripos. Joining the Geological Survey of India in 1874 , he began his scientific career in the mountains of Kashmir, of which he made a successful pioneer geological exploration. While there his opportunities for sport continued to foster his interest in zoology, and he soon acquired a good knowledge of the mammals and birds of the country. The great collection of Tertiary mammalian remains in the Indian Museum at Calcutta then attracted his attention, and he began a systematic study of these fossils, which he described in the Palaeontologia Indica.

With little material for comparison in India, and needing the corresponding collections in the British Museum for reference, Mr. Lydekker soon recognised the necessity of returning to London if his work was to be exhaustive. $\mathrm{He}$ accordingly retired from the Indian Survey in 1882 , had the fossils from Calcutta sent in instalments to London, and by 1887 had completed the fine series of volumes describing not only the Siwalik Vertebrata, but also the pre-Tertiary Vertebrata of India. At the same time, between 1885 and 1887 , Mr. Lydekker prepared for the British Museum a catalogue of the fossil mammals in the department of geology (in five parts), which was followed by similar catalogues of the fossil reptiles and amphibians (four parts, I888-9o), and fossil birds (one part, I89r). Though presenting only a somewhat hasty and superficial view of the subject, these catalogues were at the time of real utility; and they are noteworthy as the first systematic attempt to correlate the European with the more recently discovered American fossils.

In 1893, and again in 1894, Mr. Lydekker visited the Argentine Republic and spent some months in studying the wonderful collection of fossil vertebrates in the La Plata Museum. His work was published in two handsomely illustrated volumes ("Anales del Museo de La Plata," tomos II., III.), and gave the first satisfactory account of several of the peculiar extinct vertebrates of South America. His descriptions of ancestral Vetacea from the Tertiary, and Dinosaurian remains from the Cretaceous, formations are especially valuable. The visits to South America led Mr. Lydekker to appreciate more thoroughly the need for considering the evidence of fossils when dealing with questions of geographical distribution, and in 1896 he published a "Geographical History of Mammals," which is in many respects his most original and important work.

While occupied with purely scientific research, Mr. Lydekker did not overlook the needs of ordinary students, amateurs, and sportsmen, and during his later years most of his numerous writings were adapted for their use. So long ago as 1889 he contributed the volume on vertebrates to the third edition of Nicholson's "Manual of Palæontology," and in I89x he co-operated with Sir William Flower in "An Introduction to the Study of Mammals." Between I893 and 1896 he also edited the "Royal Natural History," and wrote the section on vertebrata. Work of this kind was facilitated by his occupation at the British Museum in arranging the exhibited collections of mammals and reptiles in the department of zoology, where he was employed from $\mathbf{1} 896$ until the time of his death. He not only arranged the collections in an admirable manner, but also prepared several valuable guide-books. His last work was a catalogue of Ungulate mammals in the British Museum, of which three parts were published, and the fourth, completing the Artiodactyla, was left by him nearly ready for issue.

Mr. Lydekker was elected a Fellow of the Royal Society in I894, and was awarded the Lyell Medal by the Geological Society in 1902.

\section{DR. W. J. SELL, F.R.S.}

W ILLIAM JAMES SELL, university lecturer and senior demonstrator in chemistry at the University of Cambridge, died at Cambridge after a long illness on March 7 . He was born at Cambridge in 1847 , and for more than fifty years was connected with the chemical laboratories there, and contributed in no small degree to their development and success. He was barely fifteen when, on the recommendation of the master of the elementary school which he attended, he was employed at the chemical laboratory of St. John's College, at that time the only one in the University open to undergraduates. Here he learnt elementary analysis and the use of apparatus, heard the professor's lectures, and saw his experiments. He made good use of his opportunities, and soon made himself an efficient assistant. In 1865, when the Jacksonian professor of natural philosophy removed his apparatus into a new building, the room vacated by him was united with that of the professor of chemistry, and a room built above them for a students' laboratory, the first step taken by the University, in its corporate capacity as distinct from the colleges; to provide experimental training for its students. Here Sell was appointed attendant, and had charge of the apparatus, and not only assisted the professor in the experiments at his lectures, which at that time embraced physics as well as chemistry proper; but was much in demand to help the students, whose notions of making experiments were often crude. The laboratory was a poor place at.best in comparison with modern laboratories, but it grew and became filled with students, to which result Sell's help contributed not a little.

In I870 Sell married, and soon after entered Christ's College and matriculated in the University. He had acquired a good knowledge of chemistry, and of some other branches of natural science, and knew a little of modern languages, but no degree could be obtained at Cambridge without some acquaintance with Latin and Greek, and he had not learnt either. It was a formidable task to begin now, but he faced it with his usual quiet determination, studying: Latin and Greek at all times when his duties at the labora-

No. 2374, voL. 95] 